\title{
Meta
}

Journal des traducteurs

Translators' Journal

\section{"Unusuality" and Rhetorical Effect : A Machine-Assisted Investigation of the Language of Newspaper Headlines}

\section{Alan Partington}

Volume 43, numéro 3, septembre 1998

URI : https://id.erudit.org/iderudit/003795ar

DOI : https://doi.org/10.7202/003795ar

Aller au sommaire du numéro

Éditeur(s)

Les Presses de l'Université de Montréal

ISSN

0026-0452 (imprimé)

1492-1421 (numérique)

Découvrir la revue

Citer cet article

Partington, A. (1998). "Unusuality" and Rhetorical Effect : A Machine-Assisted Investigation of the Language of Newspaper Headlines. Meta, 43(3), 454-455. https://doi.org/10.7202/003795ar
Résumé de l'article

On fait ici état d'une étude de 2500 manchettes tirées de la presse de langue anglaise : les considérations portent sur les mécanismes de modifications de citations et d'expressions toutes faites afin de produire des formulations "inusitées" dans la langue. 


\section{BLOC-NOTES}

\section{"UNUSUALITY" AND RHETORICAL EFFECT: A MACHINE-ASSISTED INVESTIGATION OF THE LANGUAGE OF NEWSPAPER HEADLINES}

\section{Résumé}

On fait ici état d'une étude de 2500 manchettes tirées de la presse de langue anglaise: les considérations portent sur les mécanismes de modifications de citations et d'expressions toutes faites afin de produire des formulations «inusitées» dans la langue.

\section{Abstract}

This article briefly discusses the use of "semi-preconstructed phrases" in a corpus of English language newspaper headlines to produce novel collocational effects.

Having read the paper Littérature et titres de presse : le cas italien by Michel Bastiaensen in Meta, 39 (1), I would like to propose a study I have carried out on the headlines from the British Press.

I downloaded a total of 2,500 headlines from the CD-ROM of The Independent newspaper - 500 from each of the Home news, International news, Arts, Business and Sports sections of the paper. With the help of colleagues, these were scrutinized for any occurrence of preconstructed word strings in the original or adapted form. Whereas Bastiaensen is interested in the intertextuality of headlines and literature, I was looking for any kind of "citation" - from literature, popular music, liturgy, proverbs, sayings to fixed collocations.

All these kinds of citations are more often than not altered in some way in headlines. It was possible to isolate the following mechanisms of alteration:

i) substitution: 8 Jan: Columbus paraded as allAmerican villain (usually All-American hero);

ii) reformulation: 2 Feb: The kooky that didn't crumble (us. That's the way the cookie crumbles);

iii) abbreviation: 8 Jan: Once a Catholic (us. Once a Catholic, always a Catholic);

iv) expansion: 16 Jan: Songs from an Age of Innocence (us. Songs of Innocence and The Age of Innocence)

Wherever the phraseology is left intact, the context in which a preconstructed phrase appears gives its elements different lexical weight than in its usual use (e.g. 3 July: Rugby: Wales set for trying where "trying time" has both its usual sense of "difficult period", but also the unusual one of scoring tries).

It was felt that a large enough collection of such items would give us some kind of indication as to what the average reader of the paper is expected to recognize about his/her culture, what is the common core of their cultural knowledge, or, in Hymesian terms, their communicative competence.

Batiaensen interprets these phenomena in terms of traditional rhetorical and literary mechanisms such as metaphor, metonymy and so on. I suggest it may also be possible to interpret them according to some of the modern linguistic theories on phraseology.

A number of authors, including Twaddel (1972), Anttila (1972) and Ladefoged (1972), Bolinger (1976), and Sinclair (1987) see collocation as one of the two main organising features of text. The other what Sinclair calls the "open choice principle", sees language production as a continuous series of openended choices, "a series of slots which have to be filled from a lexicon" (p. 320), the only restraints being grammatical, that is, that only items from certain word classes may appear in such and such a slot. However, in practice we find that possible slot choices are massively reduced. Constraints other than the grammatical are in play in texts. Apart from register (which is itself bound up with the concept of "acceptable" collocation), the further constraints are called, as a class, "the idiom principle" which states that the openness of choice is not available to the same extent at every point along the syntagmatic progression of an utterance, but that "the language user has available to him a large number of semi-preconstructed phrases that constitute single choices, even though they appear to be analysable into segments" (p. 320).

It is by no means clear, at first sight, why this should be so. It may well be the case that the language user needs to store in his memory both the single vocabulary items and a lexicon of "semi-preconstructed phrases", the number of which is probably in excess of the number of vocabulary items used productively by the individual. It would seem counterproductive to store linguistic information in this way. The answer must be that the effort saved by making far fewer slot-filling choices in real-time, that is, in the process of communication, easily outweighs the disadvantages of unwieldy storage.

If this is so, if the raison d'être of the idiom-collocation principle is to save processing time and effort, then it would tend to be at its most dominant in on-

Meta, XLIII, 3, 1998 
line, spontaneous discourse, i.e. conversation. We might expect semi-preconstructed phrases to be less common in written texts where time constraints are less of a problem (although in many written genres too, especially impersonal ones - legal documents, scientific/medical papers, etc. - pre-cooked expressions are vital, even diagnostic, elements). But in creative writing collocation remains an important principle as much for the effects that can be produced by its exploitation as its conventional cohesive power. In linguistic terms, the creative writer retains the option of treating even tightly compact preconstructed phrases as capable of analysis into its constituent elements - of introducing the open-choice principle into the idiom. Whenever a preconstructed phrase is reanalysed in this way, the effect on the text is revitalizing.

The desire to achieve novel collocational effects I have called the search for "unusuality". These effects were, in fact, found to be most common in the Arts section of the paper (book/film/theatre reviews, cultural pieces, etc.) where the time limits on the production of articles are less strict and where the author can therefore be more creative than is generally the case for say the news sections in which these effects are rather rare.

The question remains as to why this mechanism should be so popular in newspapers (and in one or two other text types such as advertising). It is probable that a major part of the intended perlocutionary effect of these devices is to allow to compliment themselves on having "solved" the allusion. This "smugness effect" helps create a bond between newspaper and reader (in advertising between product and consumer).

ALAN PARTINGTON

University of Bologna, Bologna, Italy

\section{REFERENCES}

ANTTILA, R. (1972) : An Introduction to Historical and Comparative Linguistics, New York, Macmillan.

BAKER, M. and M. McCARTHY (1990) : "Multiword units and things like that", University of Birmingham, ELR.

BASTIAENSEN, M. (1994) : "Littérature et titres de presse : le cas italien", Meta, 39 (1), pp. 229-240.

BENSON, M. (1985) : "Collocations and Idioms", R. Ilson (Ed.), Dictionaries, Lexicography and Language Learning, Oxford, Pergamon, The British Council, pp. 61-68.

BENSON, M., BENSON, E. and R. ILSON (1986) : The BBI Combinatory Dictionary of English, Amsterdam, Benjamins.

BOLINGER, D. (1976): "Meaning and Memory", Forum Linguisticum, 1, pp. 1-14

CARTER, R. (1987) : Vocabulary, London, Allen \& Unwin.

CHIARO, D. (1991): The Language of Jokes, London, Routledge.
COWIE, A. P. (1981): "The Treatment of Collocations and Idioms in Learner Dictionaries", Applied Linguistics, 2 (3), pp. 223-235.

COWIE, A. P. (1992) : "Multiword Lexical Units and Communicative Language Teaching", P. J.L. Arnaud and H. Béjoint (Eds), Vocabulary and Applied Linguistics, London, Macmillan.

CRUSE, D. (1986) : Lexical Semantics, Cambridge, Cambridge University Press.

FERNANDO, C. and R. FLAVELL (1981): On Idiom: Critical Views and Perspectives, Exeter, University of Exeter.

FIRTH, J. R. (1957) : "Modes of Meaning", Papers in Linguistics, Oxford, Oxford University Press.

HOEY, M. (1991) : Patterns of Lexis in Text, Oxford, Oxford University Press.

LADEFOGED, P. (1972) : "Phonetic Prerequisites for a Distinctive Feature Theory", A. Valdman (Ed.), Papers in Linguistics in Memory of Pierre Delattre, The Hague, Mouton.

LEECH, G. (1974) : Semantics, Harmondsworth, Penguin.

MAKKAI, A. (1972) : Idiom Structure in English, The Hague, Mouton.

REDFERN, W. (1984) : Puns, Oxford, Blackwell.

SINCLAIR, J. (1987) : "Collocation: A Progress Report", R. Steele and T. Threadgold (Eds), Language Topics: Essays in Honour of Michael Halliday, Amsterdam, Benjamins, pp. 319-331.

SINCLAIR, J. (1990): "Trust the Text: the Implications are Daunting", M. Davies and L. Ravelli (Eds), Advances in Systemic Linguistics, London, Pinter, pp. 5-19.

SINCLAIR, J. (1991): Corpus, Concordance, Collocation, Oxford, Oxford University Press. 